\title{
REMOVAL OF METHYLENE BLUE FROM WATER BY ELECTROCOAGULATION
}

\author{
Nguyen Dinh Vinh*, Vu Thi Trang \\ $T N U$ - University of Sciences
}

\begin{abstract}
This paper deals with the removal of methylene blue from water by the electrocoagulation process. The parameters such as electrode material, current density, and initial $\mathrm{pH}$ affecting the removal process were investigated in detail. The results showed that the $\mathrm{Fe}$ (anode)-Al(cathode) pair is the most proper electrode pair for the removal of methylene blue. The current density had a noticeable effect on the removal efficiency and the optimal value for application in practice was $70 \mathrm{~A} / \mathrm{m}^{2}$. The removal efficiency significantly depended on the initial $\mathrm{pH}$ of the solution. At $\mathrm{pH}$ of 7.0, more than $99 \%$ of methylene blue was removed after $40 \mathrm{~min}$. The finding in this study indicates that electrocoagulation is a promising approach that can be applied for the removal of organic dyes from water.
\end{abstract}

Keywords: methylene blue; electrocoagulation; removal efficiency; electrode; organic dyes

Received: 04/9/2020; Revised: 15/11/2020; Published: 30/11/2020

\section{LOẠI BỎ XANH METYLEN TRONG NƯỚC BÀ̀NG KEO TỤ ĐIỆN HÓA}

Nguyễn Đình Vinh*, Vũ Thị Trang

Truòng Đại học Khoa học - ĐH Thái Nguyên

\section{TÓM TẮT}

Bài báo này nghiên cứu quá trình loại bỏ xanh metylen khỏi nước bằng quá trình keo tụ điện hóa. Các thông số như vật liệu điện cực, mật độ dòng điện và $\mathrm{pH}$ của dung dịch có ảnh hưởng đến quá trình xử lý được nghiên cứu chi tiết. Kết quả cho thấy cặp điện cực Fe(anôt)-Al(catôt) là cặp điện cực phù hợp nhất cho quá trình xử lý xanh metylen. Mật độ dòng điện có ảnh hưởng đáng kể đến hiệu suất xử lý. Cường độ dòng điện tối ưu cho quá trình ứng dụng trong thực tế để lọai bỏ xanh metylen là $70 \mathrm{~A} / \mathrm{m}^{2}$. Hiệu suất xử lý cũng phụ thuộc rõ rệt vào $\mathrm{pH}$ ban đầu của dung dịch. Tại $\mathrm{pH}$ =7.0, hơn $99 \%$ xanh metylen được loại bỏ sau 40 phút. Các kết quả trong nghiên cứu này cho thấy keo tụ điện hóa là một phương pháp có nhiều tiềm năng để ứng dụng vào việc loại bỏ chất màu hữu cơ trong nước.

Từ khóa: Xanh metylen; Keo tụ điện hóa; Hiệu suất loại bỏ; Điện cục; Chất màu hũu co

Ngày nhận bài: 04/9/2020; Ngày hoàn thiện: 15/11/2020; Ngày đăng: 30/11/2020

* Corresponding author. Email: vinhnd@tnus.edu.vn https://doi.org/10.34238/tnu-jst.3552 


\section{Introduction}

Methylene blue (MB) has been widely used in different industries such as paper and plastics, leather, pharmaceuticals, cosmetics, dyestuffs, textiles, etc. to color the products [1], [2]. Consequently, the wastewater of these industries contains a considerable amount of MB. This dye is difficult to degrade because of its complex structure which contains aromatic amines, such as nitro-aromatic and phenolic compounds [3], [4]. The existence of MB in water even with a low concentration is highly visible and undesirable. The degradation by-products of MB have serious effects on the environment because they are toxic aromatic compounds [3]. Therefore, the removal of $\mathrm{MB}$ from wastewater before discharged into the environment is essential, otherwise, it will cause many problems with human health and environmental pollution [5].

$\mathrm{MB}$ can be removed from water by various methods such as adsorption, coagulation, filtration, ion exchange, oxidation, and biodegradation [6]. However, the drawbacks of the mentioned methods including chemical expense, difficult operation, production of new pollutants, and time consumption limit the application in practice [7]. In recent years, electrocoagulation (EC) has been insensitively and applied for the removal of organic dyes from wastewater [8]. The reported results show that it is a promising approach for the prevention of pollution problems from industrial effluents. In the contribution [9], the authors used EC to remove congo red from wastewater and found that the removal efficiency reached $98 \%$ with the energy consumption of $0.46 \mathrm{KWh}$ per $1000 \mathrm{~L}$ of congo red solution. In the study [10], EC was used for removal of color from the solution containing dye Basic Yellow 28 and the results showed that the color can be completely removed after about 7 minutes. The main advantage of this technology is its environmental compatibility, high efficiency, and safety because it operates at the ambiance conditions [11].

In the present work, the EC process is studied and utilized to eliminate MB from water. The key factors such as electrode material, current density, and initial $\mathrm{pH}$ which govern the removal process are investigated in detail.

\section{Materials and Methods}

The chemicals including $\mathrm{MB}, \mathrm{NaCl}, \mathrm{NaOH}$, and $\mathrm{HCl}$ were analytical grade and used directly without any further purification. The electrode materials used in this study were $\mathrm{Fe}$ (99\%) and Al (99.5\%). All solutions were prepared with double-distilled water (DDW). A $1000 \mathrm{mg} / \mathrm{L}$ solution of MB was prepared by dissolving $1 \mathrm{~g}$ of methylene blue in $1 \mathrm{~L}$ of DDW and the obtained solution was used to prepare working solutions by diluting with DDW. The electrocoagulation system used in this study is presented in Figure 1.

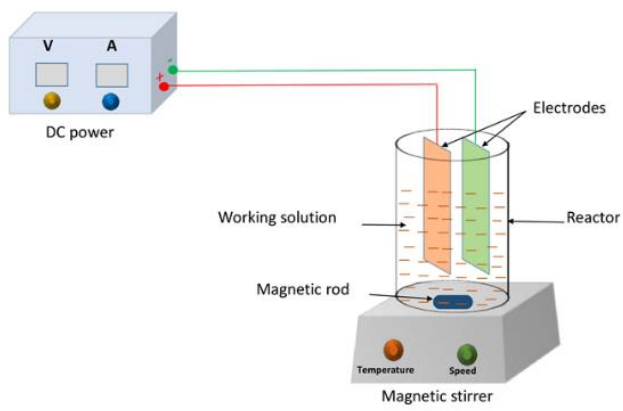

Figure 1. Electrocoagulation system

In this system, two electrodes with $2 \mathrm{~cm}$ in width and $5 \mathrm{~cm}$ in length were placed in a 250 $\mathrm{ml}$ reactor containing $200 \mathrm{~mL}$ of the working solution. The distance between two electrodes was $15 \mathrm{~mm}$ and the electrodes were connected to a DC power by electric wires. A magnetic stirrer was used to homogenize the reaction system. To study the effect of the electrode and, the experiments were carried out at $\mathrm{pH}=7$, with current density $(\mathrm{J})$ of 50 $\mathrm{A} / \mathrm{m}^{2}, \mathrm{MB}$ initial concentration $\left(C_{o}\right)$ of 30 $\mathrm{mg} / \mathrm{L}$, and electrolyte $(\mathrm{NaCl})$ concentration of $1 \%$. The materials used for electrodes were 
steel $(\mathrm{Fe})$ and aluminum $(\mathrm{Al})$. Four pairs of electrodes including $\mathrm{Fe}-\mathrm{Fe}, \mathrm{Al}-\mathrm{Al}, \mathrm{Al}$ (anode) -Fe (cathode), and $\mathrm{Fe}$ (anode)-Al(cathode) were used to find the optimum electrode pair and the reaction time were changed from 5 to 90 minutes. In the study of the effect of current density, the experiments were carried with electrodes pair $\mathrm{Fe}$ (anode)-Al(cathode) and the current density was varied from 50 to $100 \mathrm{~A} / \mathrm{m}^{2}$. Reaction time was changed from 5 to 60 minutes. To study the effect of $\mathrm{pH}$ on MB removal performance, the experiments were performed the under the following conditions: $\mathrm{MB}$ initial concentration of 30 $\mathrm{mg} / \mathrm{l}$, the current density of $70 \mathrm{~A} / \mathrm{m}^{2}$ ), electrolytes $(\mathrm{NaCl})$ of $1 \%$, electrode pair of $\mathrm{Fe}$ (anode)- $\mathrm{Al}$ (cathode) and the initial $\mathrm{pH}$ of the solution was adjusted from 3.0 to 11.0. The samples after treatment were centrifuged at $4000 \mathrm{rpm}$. The concentration of MB in the remained in the solutions was determined by photo spectroscopy method. The analyses were performed on a V-770 photo spectrometer. The standard line was built in the concentration range of $0-10 \mathrm{ppm}$ with a radiation wavelength of $664 \mathrm{~nm}$. The obtained solutions were diluted (if it is necessary) to lie in the standard range and measured at 664 $\mathrm{nm}$. Each sample was analyzed three times and the reported results were average values. The dye removal efficiency was calculated by the following equation:

Removal efficiency $=\frac{c_{0}-c_{t}}{c_{0}} 100$,

where $C_{o}$ is the $\mathrm{MB}$ initial concentration $(\mathrm{mg} / \mathrm{L})$ and $C_{t}(\mathrm{mg} / \mathrm{L})$ is the $\mathrm{MB}$ concentration after treated in $t$ minutes.

\section{Results and Discussion}

\subsection{Effect of electrode materials}

The electrode material is one of the key factors that affect electrocoagulation because the electrochemical reaction significantly depends on the nature of the electrodes used in a system [12]. In this study, four pairs of electrodes were tested. From the results, we found that the MB removal efficiency is remarkably low, below $10 \%$ after treated in 90 minutes when the electrodes pairs $\mathrm{Al}-\mathrm{Al}$ and $\mathrm{Al}$ (anode)-Fe(cathode) were used, indicating that these pairs are not suitable for removing $\mathrm{MB}$ from the solution. The low efficiency in these cases can be explained by the passivation of the aluminium electrode in the electrolysis process, resulting in a small amount of flocs formed.

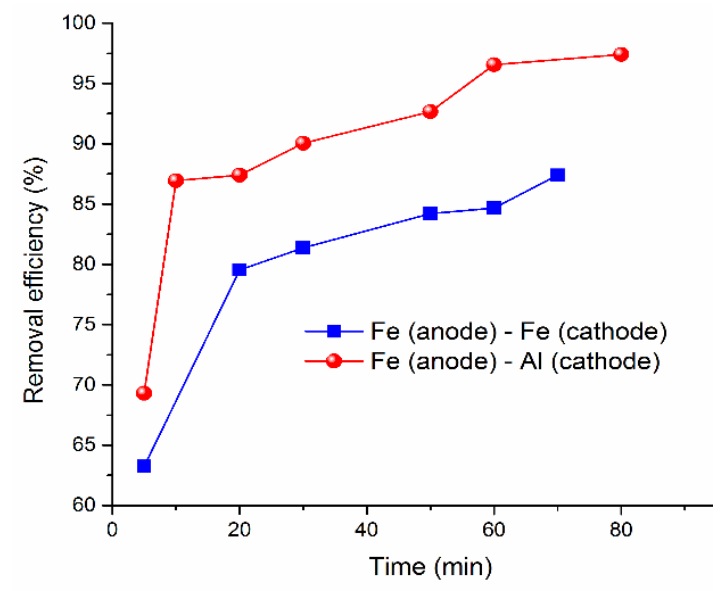

Figure 2. Effect of electrode on $M B$ removal efficiency: $\mathrm{pH}=7, \mathrm{C}_{o}=30 \mathrm{mg} / \mathrm{L}, 1 \%$ of $\mathrm{NaCl}, \mathrm{J}=50 \mathrm{~A} / \mathrm{m}^{2}$

For the Fe-Fe electrode system (Figure 2), the removal efficiency increases rapidly at the beginning of the electrolysis process. Nearly $80 \%$ of MB was removed in 20 minutes, after that the process was slowed down with the removal efficiency after 70 minutes. The mechanism for removing $\mathrm{MB}$ in this electrode system is indicated by the reactions that occur on the electrode surface as the following:

Anodes: $\mathrm{Fe}-2 \mathrm{e} \rightarrow \mathrm{Fe}^{2+}$

$\mathrm{Fe}^{2+}+2 \mathrm{OH}^{-} \rightarrow \mathrm{Fe}(\mathrm{OH})_{2}$

$2 \mathrm{Fe}(\mathrm{OH})_{2}+\mathrm{H}_{2} \mathrm{O}+\mathrm{O}_{2} \rightarrow 2 \mathrm{Fe}(\mathrm{OH})_{3}$

Cathodes:

$2 \mathrm{H}_{2} \mathrm{O}+2 \mathrm{e} \rightarrow 2 \mathrm{OH}^{-}+\mathrm{H}_{2}$

The overall reaction during electrolysis is as follows:

$4 \mathrm{Fe}+6 \mathrm{H}_{2} \mathrm{O}+3 \mathrm{O}_{2} \rightarrow 4 \mathrm{Fe}(\mathrm{OH})_{3}$

Newly formed $\mathrm{Fe}(\mathrm{OH}) 3$ flocs have large surface areas, which are favored for the effective adsorption of dissolved organic compounds and capturing of suspended particles [13]. 
For the $\mathrm{Fe}$ (anode) - $\mathrm{Al}$ (cathode) electrode system, the MB removal rate is much faster in comparison to the $\mathrm{Fe}-\mathrm{Fe}$ system. More than $85 \%$ of $\mathrm{MB}$ was removed in only $10 \mathrm{~min}$, after that, the rate is slower and finally reaches $97.34 \%$ after $90 \mathrm{~min}$.

Anodes:

Anodes: $\mathrm{Fe}-2 \mathrm{e} \rightarrow \mathrm{Fe}^{2+}$

$\mathrm{Fe}^{2+}+2 \mathrm{OH}^{-} \rightarrow \mathrm{Fe}(\mathrm{OH})_{2}$

$2 \mathrm{Fe}(\mathrm{OH})_{2}+\mathrm{H}_{2} \mathrm{O}+\mathrm{O}_{2} \rightarrow 2 \mathrm{Fe}(\mathrm{OH})_{3}$

Cathodes:

$2 \mathrm{H}_{2} \mathrm{O}+2 \mathrm{e} \rightarrow 2 \mathrm{OH}^{-}+\mathrm{H}_{2}$

$\mathrm{Al}+\mathrm{OH}^{-}+\mathrm{H}_{2} \mathrm{O} \rightarrow\left[\mathrm{Al}(\mathrm{OH})_{4}\right]^{-}+\mathrm{H}_{2}$

$\left[\mathrm{Al}(\mathrm{OH})_{4}\right] \leftrightarrow \mathrm{Al}(\mathrm{OH})_{3}+\mathrm{OH}^{-}$

The overall reaction during electrolysis is as follows:

$\mathrm{Fe}+\mathrm{Al}+\mathrm{O}_{2}+4 \mathrm{H}_{2} \mathrm{O} \rightarrow \mathrm{Fe}(\mathrm{OH})_{3}+\mathrm{Al}(\mathrm{OH})_{3}+\mathrm{H}_{2}$

Like the above electrode system, $\mathrm{Fe}(\mathrm{OH})_{3}$ are generated adsorbs dissolved organic compounds in the solution and captures suspended particles, reducing the concentration of MB. However, one difference in this electrode system is that it produces not only $\mathrm{Fe}(\mathrm{OH})_{3}$ but also $\mathrm{Al}(\mathrm{OH})_{3}$. $\mathrm{Al}(\mathrm{OH})_{3}$ also works as $\mathrm{Fe}(\mathrm{OH})_{3}$, reducing the concentration of MB. Therefore, MB removal efficiency in the $\mathrm{Fe}-\mathrm{Al}$ electrode system is higher than that of the $\mathrm{Fe}-\mathrm{Fe}$ electrode system. From the results, it can be also seen that the MB removal efficiency significantly depends on the electrolysis time. This dependence is reasonable because the amount of flocs formed relates to the amount of metal ion released during electrolysis which is proportional to the electrolysis time (Faraday's law). When compared two equations (6) and (13), it can be found that in the $\mathrm{Fe}-\mathrm{Al}$ system, besides the $\mathrm{Fe}(\mathrm{OH})_{3}$ flocs, there are additional $\mathrm{Al}(\mathrm{OH})_{3}$ flocs, although two systems consume the same amount of charge. Therefore, concerning the electric efficiency in the production of flocs, the Fe$\mathrm{Al}$ system more efficient that the $\mathrm{Fe}-\mathrm{Fe}$ system. Thus, the Fe-Al system was selected for the next experiments.

\subsection{Effect of current density}

Current density $(\mathrm{J})$ is an important parameter in the EC process because it affects the cost of the system operation [14]. $\mathrm{J}\left(\mathrm{A} / \mathrm{m}^{2}\right)$ is calculated as the following equation:

$$
I=\frac{I}{S} \text { (14), }
$$

where I (A) is the current intensity and $\mathrm{S}\left(\mathrm{m}^{2}\right)$ is the surface area of the electrode. In this work, to find the optimal condition, $\mathrm{J}$ was varied in the range of $50-100 \mathrm{~A} / \mathrm{m}^{2}$, respectively. The dependence of the $\mathrm{MB}$ removal efficiency on $\mathrm{J}$ is shown in Figure 3.

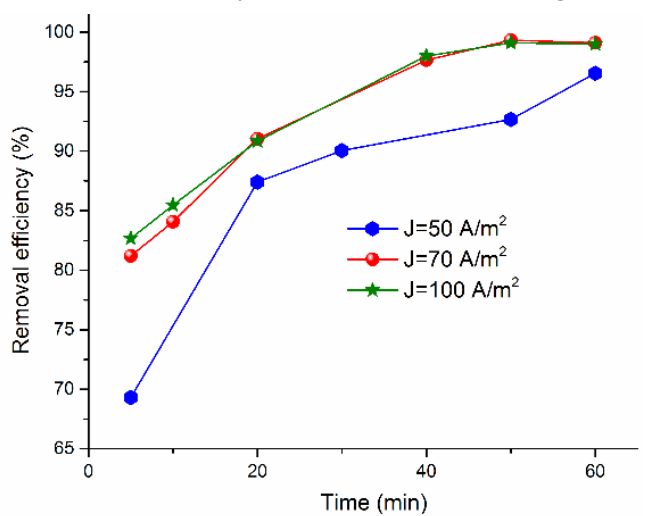

Figure 3. Effect of current density on the $M B$ removal efficiency

It can be seen that when $\mathrm{J}$ increases from 50 to $70 \mathrm{~A} / \mathrm{m}^{2}$, the removal efficiency increases remarkably, more than $12 \%$ after $5 \mathrm{~min}$. When the time increases, the difference reduces with $97.41 \%$ for $\mathrm{J}$ of $50 \mathrm{~A} / \mathrm{m}^{2}$ and $99.10 \%$ for $\mathrm{J}$ of $70 \mathrm{~A} / \mathrm{m}^{2}$ after $70 \mathrm{~min}$ of the treatment. This trend can be explained from the fact that the amount of flocs depends on the amount of metal ions formed at the electrodes which are directly related to the current passing through the electrodes according to Faraday's law.

Inversely, when $\mathrm{J}$ increases from 70 to 100 $\mathrm{A} / \mathrm{m}^{2}$, the removal efficiency of both cases is similar, indicating that $\mathrm{J}$ of $70 \mathrm{~A} / \mathrm{m}^{2}$ is sufficient to produce the flocs which are enough for the removal of MB. Concerning 
energy efficiency, $J$ of $70 \mathrm{~A} / \mathrm{m}^{2}$ is the most proper value for this process because of the high rate of the process and the saving of energy [15]. Therefore, this value will be used in the next experiments. According to the experimental data, with $\mathrm{J}$ of $70 \mathrm{~A} / \mathrm{m}^{2}$, the time required for the removal of more than $99 \%$ of $\mathrm{MB}$ is 50 minutes.

\subsection{Effect of initial $\mathrm{pH}$}

In the EC process, the rate of the formation of flocs noticeably depends on the $\mathrm{pH}$ of the reaction system because the precipitation of metal ion relies on the concentration of the hydroxyl ion [7]. To study the effect of the initial $\mathrm{pH}$ value of the dye solution, the experiments were carried out in three mediums with five values of $\mathrm{pH}$ including 3.0 and 5.0 (acidic), 7.0 (neutral), and 9.0 and11.0 (basic). The effect of the initial $\mathrm{pH}$ is presented in Figure 4.

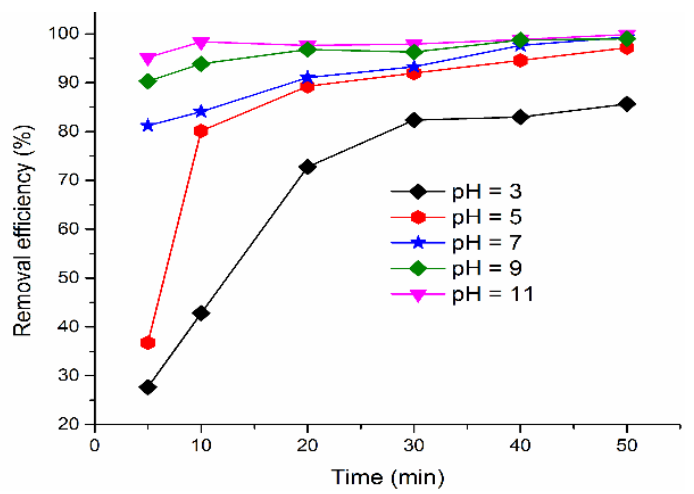

Figure 4. Effect of $p H$ on the $M B$ removal efficiency It can be seen that at the beginning of the process, the removal efficiency is significantly affected by $\mathrm{pH}$ value of the solution. Namely, at $\mathrm{pH}$ of 3.0, only $27.64 \%$ of MB was removed, while this value for $\mathrm{pH}$ of 7.0 and 11.0 is 81.2 and $90.3 \%$, respectively. The effect of $\mathrm{pH}$ can be explained that in the acidic solution, ion $\mathrm{OH}$ formed at the cathode will react with ion $\mathrm{H}+$, hence the precipitation of the metal ions is prevented. On other hand, in the basic solution, with an excess of $\mathrm{OH}^{-}$in the solution at the beginning not only the precipitation of $\mathrm{Fe}(\mathrm{OH})_{3}$ is formed but also aluminum is dissolved to give $\mathrm{Al}(\mathrm{OH})_{3}$, which will accelerate the removal process. When the electrolysis increased, ion $\mathrm{OH}^{-}$in the acidic and neutral solution increases, resulting in an increase in the removal efficiency. There is no difference between the cases of $\mathrm{pH}=7$ and $\mathrm{pH}=11$ after $40 \mathrm{~min}$, indicating that the removal process can be performed well without using the chemical to adjust the $\mathrm{pH}$ of the solution.

\section{Conclusion}

The removal of MB by using the electrocoagulation method has been studied in detail. The removal process is significantly dependent on the material used for electrodes, current density, and initial $\mathrm{pH}$ of the solution.

Four electrode pairs including $\mathrm{Fe}-\mathrm{Fe}, \mathrm{Al}-\mathrm{Al}$, $\mathrm{Al}$ (anode)-Fe(cathode), $\mathrm{Fe}$ (anode)-Al(cathode) pair have been tested for the ability in removing $\mathrm{MB}$ in which the $\mathrm{Fe}$ (anode)$\mathrm{Al}$ (cathode) pair is the most effective. The effect of current density on the removal efficiency has been evaluated and $\mathrm{J}$ of 70 $\mathrm{A} / \mathrm{m}^{2}$ shows the most proper value for practical. The higher $\mathrm{pH}$ is the shorter time is required for the removal of MB. According to the obtained data in this study, it can be concluded that the electrocoagulation process with the $\mathrm{Fe}-\mathrm{Al}$ electrode pair is an effective means to remove cationic dyes as MB from water and is a promising approach that can be applied for the removal of organic dyes from water.

\section{Acknowledgments}

This research is funded by the Vietnam Ministry of Education and Training under grant code B2019-TNA-17.

\section{REFERENCES}

[1]. L. Bulgariu et al., "The utilization of leafbased adsorbents for dyes removal: A review," Journal of Molecular Liquids, vol. 276, pp. 728-747, 2019.

[2]. C. A. Martínez-Huitle, and E. Brillas, "Decontamination of wastewaters containing synthetic organic dyes by electrochemical methods: A general review," Applied 
Catalysis B: Environmental, vol. 87, no. 3-4, pp. 105-145, 2009.

[3]. X. Jin, M. qin Jiang, X. quan Shan, Z. guo Pei, and Z. Chen, "Adsorption of methylene blue and orange II onto unmodified and surfactantmodified zeolite," Journal of Colloid and Interface Science, vol. 328, no. 2, pp. 243247, 2008.

[4]. L. A. R. Giusto, F. L. Pissetti, T. S. Castro, and F. Magalhães, "Preparation of Activated Carbon from Sugarcane Bagasse Soot and Methylene Blue Adsorption,"Water, Air, \& Soil Pollution, vol. 228, no. 7, p. 249, 2017.

[5]. N. Puvaneswari, J. Muthukrishnan, and P. Gunasekaran, "Toxicity assessment and microbial degradation of azo dyes," Indian Journal of Experimental Biology, vol. 44, pp. 618-626, 2006.

[6]. M. Hasanpour, and M. Hatami, "Photocatalytic performance of aerogels for organic dyes removal from wastewaters: Review study," Journal of Molecular Liquids, vol. 309, p. 113094, 2020.

[7]. A. K. Darban, A. Shahedi, F. Taghipour, and A. Jamshidi-Zanjani, "A review on industrial wastewater treatment via electrocoagulation processes," Current Opinion in Electrochemistry, vol. 22, pp. 154-169, 2020.

[8]. Z. Al-Qodah, Y. Al-Qudah, and E. Assirey, "Combined biological wastewater treatment with electrocoagulation as a post-polishing process: A review," Separation Science and Technology, vol. 55, no. 13, pp. 2334-2352, 2020.

[9]. N. Mohammadlou, M. H. Rasoulifard, and M. Vahedpour, "The Kinetic and Thermodynamic Study for Decolorization of
Congo red from Aqueous Solution Using Electrocoagulation Process," Journal of Applied Chemical Research, vol. 142, pp. 123-142, 2014.

[10]. N. Daneshvar, A. R. Khataee, and N. Djafarzadeh, "The use of artificial neural networks (ANN) for modeling of decolorization of textile dye solution containing C. I. Basic Yellow 28 by electrocoagulation process," Journal of Hazardous Materials, vol. 137, no. 3, pp. 1788-1795, 2006.

[11]. J. N. Hakizimana et al., "Electrocoagulation process in water treatment: A review of electrocoagulation modeling approaches," Desalination, vol. 404, pp. 1-21, 2017.

[12]. C. E. Barrera-Díaz, V. Lugo-Lugo, and B. Bilyeu, "A review of chemical, electrochemical and biological methods for aqueous Cr(VI) reduction," Journal of Hazardous Materials, vol. 223-224, pp. 1-12, 2012.

[13]. I. Kabdaşl1, I. Arslan-Alaton, T. ÖlmezHanc1, and O. Tünay, "Electrocoagulation applications for industrial wastewaters: a critical review," Environmental Technology Reviews, vol. 1, no. 1, pp. 2-45, 2012.

[14]. R. H. Al Anbari, S. M. Alfatlawi, and J. H. Albaidhani, "Removal of some heavy metals by electrocoagulation," Advanced Materials Research, vol. 468-471, no. November 2012, pp. 2882-2890, 2012.

[15]. O. Sahu, B. Mazumdar, and P. K. Chaudhari, "Treatment of wastewater by electrocoagulation: a review," Environmental Science and Pollution Research, vol. 21, no. 4, pp. 2397-2413, Feb. 2014. 